\title{
Towards the utilization of waste glass powder in sustainable cement based overlays
}

\author{
Eukasz Sadowski ${ }^{1, *}$ \\ ${ }^{1}$ Wroclaw University of Science and Technology, Wybrzeże Wyspiańskiego 27, 50-370 Wroclaw, \\ Poland
}

\begin{abstract}
The article focuses on the possibility of utilizing waste glass powder in cement based overlays for sustainable construction. In the work, a study was carried out on the evaluation of the influence of waste glass powder, which modifies the overlay, on its adhesion to a concrete substrate. The waste glass powder was added in various amounts in relation to the binder mass. The adhesion tests were conducted using the commonly known pull-off method. The preliminary test results are presented and discussed in the article.
\end{abstract}

\section{Introduction}

Innovations in civil engineering and materials science have recently not been possible without considering sustainable development [1]. Some parts of these innovations may be successfully applied to the overlay industry. More attempts have recently been focused on the modification of the material of an overlay with different additives. These attempts can be made during the construction or repair of a concrete structure [2-3]. As estimated in [4], around $50 \%$ of Europe's annual construction budget is spent on refurbishment and repair. To achieve sustainable repair, waste material should be utilized.

Waste mineral powders, such as fly ash, blast-furnace slag or waste perlite powder are successfully used for the production of cement and concrete [5]. As pointed out in [6], waste glass powder can also further contribute to sustainability in construction. According to [7], waste glass can mainly be sourced from the production of container glass (bottles, jars), flat glass (windows, windscreens), bulb glass (light globes) or cathode ray tube glass (TV screens, monitors, etc). Waste glass powder has recently become popular as a supplementary cementitious material in glass-based concrete [8], architectural cement mortars [9], cement paste [10] or geopolymer paste [11]. To the best of my knowledge, there is no application of waste glass powder in the overlay industry. Thus, there is a need to perform research towards the utilization of waste glass powder in sustainable cement based overlays.

The durability of multi-layered concrete elements depends on the proper adhesion between an overlay and a concrete substrate [12]. According to literature reports, some researchers try to modify normal-strength concrete with various additives [13-17]. These tests can be aimed at achieving the required adhesion value between an overlay and substrate without the need for special treatments to prepare the surface of the concrete substrate. For

\footnotetext{
*Corresponding author: lukasz.sadowski@pwr.edu.pl
} 
example, Moghtadaei, Mohammadi et al. [18, 19] conducted research on the adhesion between an overlay with the addition of metakaolin and a concrete substrate, and showed that this additive increases this adhesion. In turn, Nagaonkar et al. [20] showed an increase in the adhesion of an overlay made with the addition of silica fume to a concrete substrate. On the other hand, $L i[21]$, in order to increase the adhesion between concrete layers, modified them with the addition of fly ash derived from the combustion of hard coal. These additives have recently been more frequently sourced from industrial wastes.

There are no reports in literature of whether the modification of an overlay with additives in the form of glass powder, which is a waste material in construction, favourably affects the adhesion of this overlay to a concrete substrate. This work is an initial contribution to filling this knowledge gap. The preliminary attempts of this utilization will be presented.

\section{Materials and methods}

The research involved two model two-layer concrete test elements with dimensions of $600 \mathrm{x}$ $1200 \mathrm{~mm}$ and a total thickness of $150 \mathrm{~mm}$ (Fig. 1). The substrate was $125 \mathrm{~mm}$ thick and the overlay was $25 \mathrm{~mm}$ thick.

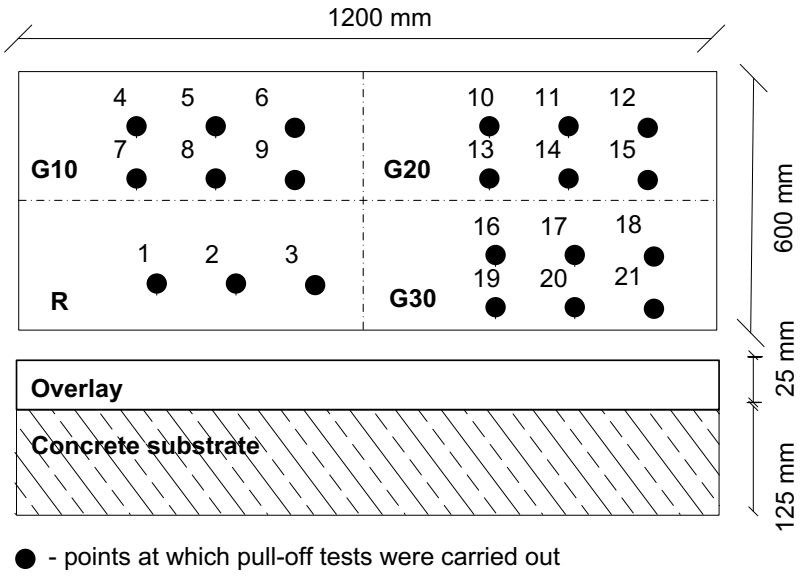

Fig. 1. Scheme of the model research element with the location of the points where the pull-off tests were carried out.

Table 1 shows the weight composition of the concrete mix used to make the substrate. Concrete basalt aggregate with a maximum grain size of up to $8 \mathrm{~mm}$ and a volume density of $2.60 \mathrm{~g} / \mathrm{cm}^{3}$ was used to make the concrete substrate.

Table 1. Weight composition of the concrete mix used to make the substrate.

\begin{tabular}{|c|c|c|c|c|c|}
\hline $\begin{array}{c}\text { Portland cement } \\
\text { CEM II A-LL } \\
\mathbf{4 2 , 5} \text { R }\end{array}$ & Fly ash (FA) & Sand & $\begin{array}{c}\text { Coarse } \\
\text { aggregate } \\
\text { (up to 8 mm) }\end{array}$ & Water & $\begin{array}{c}\text { Plasticizer } \\
\text { Visco Flow } \\
\mathbf{6 9 2 0}\end{array}$ \\
\hline \multicolumn{7}{|c|}{$\left[\mathbf{k g} / \mathbf{m}^{3}\right]$} \\
\hline 352.0 & 40.0 & 724.4 & 1086.6 & 165.0 & 2.0 \\
\hline
\end{tabular}

In turn, Table 2 presents the weight compositions of the concrete mixes used to make the overlay. In the case of the overlay concrete, it was made with natural quartz aggregate with 
a maximum grain size of up to $8 \mathrm{~mm}$ and a bulk density of $2.64 \mathrm{~g} / \mathrm{cm}^{3}$. To make the concrete of both layers, quartz sand with a maximum grain size of up to $2 \mathrm{~mm}$ and a volume density of $2.62 \mathrm{~g} / \mathrm{cm}^{3}$ was used. It should be clarified that the surface of both elements was divided into four parts, each of which had an overlay with a different composition, which is given in Table 2. In the case of the first element, as presented in Figure 1, on the part marked with the letter R (reference) the top layer was made of the mixture marked R. In turn, on the part marked G, the top layer was made of waste glass powder G10, G20 and G30 containing 10, 20 and $30 \%$ of glass powder, respectively in relation to the binder mass. According to [22], Portland cement CEM $42.5 \mathrm{R}$ was used.

Table 2. Weight composition of the concrete mix used to make the overlay.

\begin{tabular}{|c|c|c|c|c|c|c|}
\hline \multirow[b]{2}{*}{$\begin{array}{c}\text { Designatio } \\
\text { n of } \\
\text { concrete } \\
\text { mix }\end{array}$} & \multicolumn{6}{|c|}{ Component of concrete mix $\left[\mathrm{kg} / \mathrm{m}^{3}\right]$} \\
\hline & $\begin{array}{c}\text { Portland } \\
\text { cement CEM } \\
\text { I 42.5 R }\end{array}$ & $\begin{array}{l}\text { Waste } \\
\text { glass } \\
\text { powder }\end{array}$ & Sand & $\begin{array}{c}\text { Coarse } \\
\text { aggregat } \\
\text { e } \\
\text { (up to } 8 \\
\text { mm) }\end{array}$ & Water & $\begin{array}{c}\text { Plasticizer } \\
\text { Master } \\
\text { Pozzolith } \\
\text { 18BV }\end{array}$ \\
\hline $\mathrm{R}$ & 352.0 & 0 & 676.0 & 1205.0 & 141.0 & 2.1 \\
\hline G10 & 316.8 & 35.2 & 676.0 & 1205.0 & 141.0 & 2.1 \\
\hline G20 & 281.6 & 70.4 & 676.0 & 1205.0 & 141.0 & 2.1 \\
\hline G30 & 246.4 & 105.6 & 676.0 & 1205.0 & 141.0 & 2.1 \\
\hline
\end{tabular}

The concrete of the surface and overlay matured naturally at an air temperature of $+20^{\circ} \mathrm{C}$ $\left( \pm 3^{\circ} \mathrm{C}\right)$ and relative air humidity of $60 \%( \pm 5 \%)$. Table 3 shows the particle size distribution of waste glass powder and Table 4 shows the chemical composition of waste glass powder. For comparison, the chemical composition of the Portland cement used in the testing is also presented.

Table 3. Grain size distribution of waste glass powder.

\begin{tabular}{|c|c|}
\hline Test sieve $(\boldsymbol{\mu m})$ & Fraction passing $(\boldsymbol{\%})$ \\
\hline 1400 & 0.0 \\
\hline 1000 & 0.2 \\
\hline 430 & 2.0 \\
\hline 150 & 8.0 \\
\hline 100 & 15.0 \\
\hline 63 & 40.0 \\
\hline$<63$ & 90.0 \\
\hline
\end{tabular}


It can be seen from Table 4 that the waste glass powder and cement CEM I 42.5R differ significantly in all the main components. The waste glass powder is mainly composed of $\mathrm{SiO}_{2}$ and $\mathrm{Na}_{2} \mathrm{O}+\mathrm{K}_{2} \mathrm{O}$, while the dominant component of the cement was $\mathrm{CaO}$ and $\mathrm{SiO}_{2}$.

Table 4. Chemical composition of waste glass powder and cement CEM I 42.5R used in the testing (data from producers)

\begin{tabular}{|c|c|c|}
\hline Component & $\begin{array}{c}\text { Content in waste glass powder, } \\
\text { (mass \%) }\end{array}$ & $\begin{array}{c}\text { Content in cement, } \\
\text { (mass \%) }\end{array}$ \\
\hline $\mathrm{SiO}_{2}$ & 71.50 & 22.18 \\
\hline $\mathrm{Al}_{2} \mathrm{O}_{3}$ & 1.25 & 5.98 \\
\hline $\mathrm{CaO}$ & 9.00 & 61.13 \\
\hline $\mathrm{MgO}$ & 4.00 & 1.12 \\
\hline $\mathrm{Na}_{2} \mathrm{O}+\mathrm{K}_{2} \mathrm{O}$ & 14.00 & 0.65 \\
\hline $\mathrm{TiO}_{2}$ & max. 0.1 & max. 0.1 \\
\hline Other & 0.15 & 8.84 \\
\hline
\end{tabular}

28 days after concreting the substrate, the overlay was made on it. Then, after 7 and 28 days, pull-off adhesion tests were carried out using the pull-off method. The location of points where the pull-off tests were performed was previously presented in Figure 1.

According to [23], the pull-off tests involved the drilling of holes in the overlay with a diameter of $50 \mathrm{~mm}$ and the gluing of steel discs, followed by detaching them from the surface of the substrate with a special actuator with the registration of the pull-off force $F_{\mathrm{b}}$. Knowing the average dimension of the diameter of the steel disc $D_{\mathrm{f}}$, the value of pull-off adhesion $f_{\mathrm{b}}$ is obtained from the following dependence (1):

$$
f_{b}=\frac{4 \cdot F_{b}}{\pi \cdot D_{f}{ }^{2}}
$$

\section{Preliminary test results}

Figure 2 shows the influence of various amounts of waste glass powder, which modify the concrete of the overlay, on the pull-off adhesion $f_{\mathrm{b}}$ to the concrete substrate. The analysis of Figure 2 shows that a 10 and $20 \%$ addition of waste glass powder in relation to binder mass does not cause the increase of the value of the pull-off adhesion $f_{\mathrm{b}}$ to the concrete substrate after 7 and 28 days. However, a 30\% addition of this waste reduces the pull-off adhesion by about $5 \%$ after 7 days, and by about $20 \%$ after 28 days. 


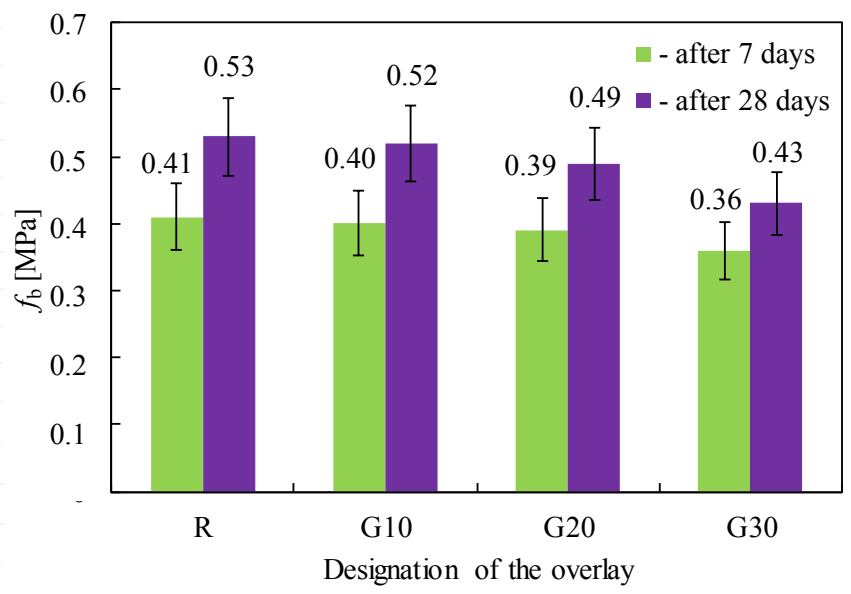

Fig. 2. Influence of different amounts of waste glass powder, which modify the concrete of the overlay, on the pull-off adhesion $f_{\mathrm{b}}$ to the concrete substrate.

\section{Conclusions}

The paper evaluates the influence of selected waste additives, which modify the concrete of the overlay, on its bond to the concrete substrate. This additive was glass powder.

The preliminary results show that the modification of the concrete of the overlay with the addition of waste glass powder in amounts of 10 and $20 \%$ of the binder mass results in the pull-off adhesion $f_{\mathrm{b}}$ value of the overlay to the substrate remaining unchanged. Increasing the amount of this powder in the concrete composition by up to $20 \%$ of the binder mass reduces the pull-off adhesion $f_{\mathrm{b}}$ value by about $5 \%$ after 7 days, and by about $8 \%$ after 28 days.

The presented preliminary results are promising when taking into account the route towards the utilization of waste glass powder in sustainable cement based overlays. Future studies will be needed and will be related mainly to the testing of the mechanical properties of modified overlays, as well as some microscopic observations.

\section{References}

1. L. Czarnecki, D. Van Gemert, Bull. Pol. Acad. Scie. Techn. Scie. 65, 6 (2017)

2. F. Leonelli, P. Di Mascio, A. Germinario, F. Picarella, L. Moretti, M. Cassata, A. De Rubeis, Appl. Scie. 7, 11 (2017)

3. A. I. Ortega, T. M. Pellicer, J. M. Adam, P. A. Calderón, Const. Build. Mater. 161 (2018)

4. G. P. Tilly, J. Jacobs, Concrete repairs: Observations on performance in service and current practice (CONREPNET Project Report, IHS BRE Press, Watford, UK, 2007)

5. P. Łukowski, Mater., 9, 10 (2016)

6. A.M. Matos, J. Sousa-Coutinho, Const. Build. Mater. 36 (2012)

7. A. Shayan, A. Xu, Cem. Concr. Res. 34, 1, (2004)

8. H. Lee, A. Hanif, M. Usman, J. Sim, H. Oh, J. Cle. Pro. 170 (2018)

9. J.X. Lu, Z.H. Duan, C.S. Poon, Const. Build. Mater. 131 (2017)

10. M. Kamali, A. Ghahremaninezhad, Const. Build. Mater. 149 (2017)

11. T. Tho-In, V. Sata, K. Boonserm, P. Chindaprasirt, J. Cle. Pro. 172 (2018) 
12. L. Courard, B. Bissonnette, A. Garbacz, Concrete Surface Engineering (CRC Press, Boca Raton, 2015)

13. Y. Shi, I. Matsui, J. Guo, Cem. Concr. Res. 34, 8 (2004)

14. A. Galińska, S. Czarnecki, IOP Conf. Ser.: Mater. Sci. Eng. 245, 3 (2017)

15. M. Nepomuceno, L. Oliveira, S. Lopes, Const. Build. Mater. 26, 1 (2012)

16. J. Tikkanen, V. Penttala, A. Cwirzen, Mag. Concr. Res. 63, 12 (2011)

17. J. Tikkanen, Const. Build. Mater. 72 (2014)

18. R. Moghtadaei, M. Mohammadi, N. Samani, S. Mousavi, Const. Build. Mater. 80 (2015)

19. M. Mohammadi, R. Moghtadaei, N. Samani, Const. Build. Mater. 51 (2014)

20. D. Nagaonkar, J. Bhusari, Int. J. Sci. Eng. Res. 5, 5 (2014)

21. G. Li, Cem. Concr. Res. 33, 6 (2003)

22. EN 197-1 (2011)

23. ASTM D7234-05 (2005) 